\title{
On the Role of Cultural Distance in the Decision to Cross-list
}

\section{OLGA DODD $^{\mathrm{a},{ }^{*}, \text { BART FRIJNS }^{\mathrm{a}} \text { and AARON GILBERT }}{ }^{\mathrm{a}}$}

${ }^{a}$ Department of Finance, Auckland University of Technology, Auckland, New Zealand

This version: May 2012

*Corresponding author. Department of Finance, Auckland University of Technology, Private Bag 92006, 1020 Auckland, New Zealand. Tel.: +64 99219999 (ext. 5423); Fax: +64 9921 9940; Email: olga.dodd@aut.ac.nz 
On the Role of Cultural Distance in the Decision to Cross-list

\begin{abstract}
This paper examines the role of culture in the choice of the destination market for cross-listing. We argue that firms cross-list in markets that have greater cultural similarities as investors are unwilling to invest in firms from culturally dissimilar markets and managers may seek to avoid potential conflicts with culturally disparate investors and managers. Employing Hofstede's (2001) Cultural Dimensions, we find strong support for the hypothesis that firms from developed markets show a greater propensity to cross-list in a country with similar values to their home market. These results are robust to a range of alternative cultural measures including modified Hofstede's scores, societal practices scores from the GLOBE project and World Values Survey scores.
\end{abstract}

Key Words: National culture, cultural distance, international cross-listing.

JEL Classifications: C24; G10. 


\section{INTRODUCTION}

The incidence of cross-listings, i.e. firms listing their shares on exchanges outside their home market, has provoked questions about the motives for this decision. One question that is still not well understood is what drives the choice of market to cross-list in (Pagano et al., 2002; Sarkissian and Schill, 2004). Numerous theories have been proposed to explain the choice of "host" market, however, none offer complete explanations for the observed cross-listing behaviour. ${ }^{1}$

One potential explanation that has been largely overlooked in this literature is culture. ${ }^{2}$ There is a growing awareness of the importance of culture in financial decision making. Specifically, studies have shown that cultural distance, a measure of the differences between cultures, provides additional explanations for the size of the flow of both debt (Aggarwal et al., 2012) and equity (Siegel et al., 2010) capital between countries, the extent of the home bias (Beugelsdijk and Frijns, 2010; Anderson et al., 2011), and the degree of cross-border M\&A activity (Ahern et al., 2012). These papers conclude that capital flows between countries that are more culturally similar are greater than those between countries that are less similar. Cross-listing, in effect, represents a form of cross-border capital flow, albeit, one where the company itself makes its shares available to foreign investors.

\footnotetext{
${ }^{1}$ see Foerster and Karolyi (1999), Errunza and Miller (2000), Merton (1987), Foerster and Karolyi (1998), Doidge et al. (2004), Fuerst (1998), and Sarkissian and Schill (2004).

${ }^{2}$ Sarkissian and Schill (2004) are the only to consider culture to date. They include cultural proximity, measured by common language and colonial ties, and show an important role of this proxy in explaining the cross-listing decision.
} 
In this paper, we argue that cultural distance is an important determinant in the choice of host market. One possible explanation is that investors in the host country may not be willing to invest in companies from culturally dissimilar markets (see e.g. Grinblatt and Keloharju, 2001). This unwillingness may be anticipated by the cross-listing firm and may reduce the propensity to list in culturally dissimilar markets. Alternatively, having investors with different social norms, beliefs and cultural values may create conflicts between the shareholders in the host market and management. As a result, firms may choose to list in culturally similar markets to avoid potential conflict (see e.g. Ahern et al., 2012). Both arguments suggest that culture should play a role in the cross-listing decision.

We empirically examine the role of cultural distance in cross-listing decisions by employing a cross-listings dataset from 45 home markets to 32 host markets obtained from Sarkissian and Schill (2009b). To measure cultural distance we use Hofstede's (2001) cultural framework, and assess the robustness of our findings by employing alternative cultural frameworks from Tang and Koveos (2008), the GLOBE project and the World Values Surveys. For developed home markets, we find a strong preference for cross-listing in culturally similar markets, even after controlling for variables that capture the traditional motives for cross-listing. This finding is robust to different measures of culture and cross-listing activity. For emerging markets, we find that cultural distance plays no role. This finding is consistent with Beugelsdijk and Frijns (2010) who find that cultural distance does not explain the foreign asset allocation of emerging markets. 
The remainder of this paper is organized as follows. Section 2 provides a background on the role of culture in the cross-listing decision. Section 3 describes our data on cross-listing activity, cultural distance and other factors that may affect cross-listing. Section 4 presents the findings from our analysis and robustness tests. We conclude in section 5.

\section{BACKGROUND ON CULTURE AND CROSS-LISTING}

Several theories and arguments have been proposed to explain the motivation to cross-list and the choice of host market. Traditional arguments for cross-listing are predominantly based on barriers (e.g. market segmentation [Stapleton and Subrahmanyam (1977)] or informational barriers [Merton, 1987]), preference for better "quality" markets (e.g. improved liquidity [Amihud and Mendelson (1986)]; stronger investor protection [Stulz (1999) and Coffee (1999)]; or stricter disclosure regimes [Fuerst (1998)]); etc. These arguments all suggest that firms look to cross-list in markets that are different to the home market.

More recent studies suggest that firms choose to cross-list in markets where it benefits the corporation's global strategy (e.g. Bancel and Mittoo, 2001), where peers are cross-listed (Pagano et al., 2002), and where it improves the firms image with their global customers (King and Mittoo, 2007). These arguments suggest that firms are more likely to cross-list in proximate markets, either geographically, economically or culturally. This idea was first amalgamated by 
Sarkissian and Schill (2004) who argue that firms choose to cross-list in familiar markets, leading to a so-called proximity preference bias.

Recently, several studies have started to examine the role of culture on financial decision making, with one strand of research focusing on how cultural differences between countries affect the cross-border flow of capital. Cultural distance, defined as the "sum of factors creating, on the one hand, a need for knowledge, and on the other hand, barriers to knowledge flow and hence also for other flows between the home and target countries" (Barkema et al., 1997, page 427), measures the frictions created by differences in social norms and behaviours. Lower cultural differences facilitate the flow of information, as investors are better able to interpret nonverbal and nuanced communications more accurately. Given the essential role of information in financial decision-making, if investors feel more comfortable about the level of knowledge and accuracy of their information, they are more likely to be willing to invest in foreign firms (Huberman, 2001).

The notion that cultural differences negatively affect capital flows between markets has been empirically confirmed. Aggarwal et al. (2012) show that debt financing is greater between more culturally similar countries. Siegel et al. (2010) find a similar effect for equity capital. Conn et al. (2005) find that greater cultural distance reduces the abnormal returns for UK companies announcing foreign acquisitions, suggesting that the market views these acquisitions as having a lower probability of success. Similarly, Ahern et al. (2012) show that cultural differences affect both merger volume and synergy gains. Beugelsdijk and Frijns (2010) and Anderson et al. (2011) 
find that investors display greater home bias (invest proportionally less in a foreign market than they should) when the foreign market is culturally dissimilar. Given that cross-listing is an alternative way of seeking cross-border investment, we postulate that culture will also affect cross-listing decisions.

One way in which cultural distance may influence the choice of host market is the attractiveness of the firm's stock to host market investors. This follows from Barkema et al. (1997) who argue that cultural differences create barriers to the flow of information. These barriers are likely to increase the difficulty in interpreting relevant information accurately and as a result reduce investors' willingness to invest (Huberman, 2001). This argument is supported empirically by Beugelsdijk and Frijns (2010) who find that investors' willingness to invest in a foreign market is negatively affected by cultural distance. The argument also finds strong support in the work of Grinblatt and Keloharju (2001), who show that Finnish investors prefer to hold stocks in Finish firms that are located close to the investors, communicate in the investor's native language (note that Finland has two official languages: Finnish and Swedish) and are run by CEOs that have the same cultural background. Managers contemplating a cross-listing are likely to be aware of foreign investors' biases. ${ }^{3}$ Managers are also equally aware of the costs of cross-listing. If crosslistings fail to generate a marked increase in shareholder base then the positive benefits (improved liquidity, reduced cost of capital, and ultimately a valuation premium) are unlikely to materialize. If investors are unwilling to invest in a company, the benefits of the cross-listing,

\footnotetext{
${ }^{3}$ Sarkissian and Schill (2009a) argue that this proximity bias in selecting a host market is driven by managers' beliefs that investors are less willing to invest in companies that are unfamiliar to them.
} 
such as increased liquidity, will fail to compensate for the increased costs from the additional listing.

Another possible way in which culture may affect cross-listing is that managers themselves may be unwilling to cross-list in culturally distant markets. The purpose of cross-listing, as pointed out by Stapleton and Subrahmanyam (1977) and Merton (1987), is to broaden the firm's investor base. A broader shareholder base may expose the company to shareholders who have different cultural values and beliefs. These different beliefs may influence the way in which they view managerial practices and decisions. Siegel et al. (2008) note that greater differences in egalitarianism (one type of cultural distance) increase transaction costs for cross-border investments because of the impact of egalitarianism on managerial behaviour and policy-making. Attempting to bridge differences in views will cost a firm time, energy and effort and may lead to conflicts between management and shareholders (Ahern et al., 2012). As a result, firms may be more comfortable only cross-listing in those countries where business practices and cultural norms are relatively similar to their home market, purely as a way of reducing the risk of potential conflicts.

\section{DATA AND SUMMARY STATISTICS}

\subsection{CULTURAL DISTANCE}

To examine the effect of cultural distance on cross-listing activity, we rely on the cultural framework of Hofstede (2001). Hofstede's (2001) culture scores are based on the responses of 
IBM managers in various countries to a survey of their beliefs and social norms. ${ }^{4}$ Each of the countries is given a score on four cultural dimensions, Uncertainty Avoidance; Individualism; Power Distance; and Masculinity. ${ }^{5}$

To compute cultural distance, we follow standard practice and use the Euclidean distance variant of Kogut and Singh (1988). This cultural distance measure has been employed extensively in the literature (e.g. Chakrabarti et al., 2009; Drogendijk and Slangen, 2006; Aggarwal et al., 2012). Specifically, we define cultural distance $\left(C D_{i j}\right)$ between home market $i$ and host market $j$ as:

$$
C D_{i j}=\sqrt{\sum_{k=1}^{K}\left\{\left(I_{k j}-I_{k i}\right)^{2} / V_{k}\right\}},
$$

where $I_{k j}$ is country $j$ 's score on the $k$ th cultural dimension, $I_{k i}$ is the score of country $i$ on this dimension, and $V_{k}$ is the variance of the score of the dimension. We calculate $C D_{i j}$ for every possible combination of home and host market in our sample.

\footnotetext{
${ }^{4}$ Hofstede's (2001) culture scores have been used widely in numerous empirical studies and research field. Kirkman et al. (2006) provide a comprehensive survey of the literature that employs Hofstede's cultural values framework, citing more than 150 empirical studies.

${ }^{5}$ Uncertainty Avoidance refers to the extent to which people are uncomfortable with uncertain or unstructured situations and within the finance literature has been linked to risk aversion. Individualism reflects the degree to which a society emphasizes the individual as opposed to the group. Power Distance refers to the degree to which a society views an unequal distribution of power as appropriate and Masculinity refers to the emphasis placed on 'masculine' values such as competition, ambition and acquisition versus 'feminine' values such as nurturing, caring and humility.
} 


\subsection{CROSS LISTING ACTIVITY}

We measure cross-listing activity between two countries by the number of companies crosslisting from their home market in each host market. We obtain these data from Sarkissian and Schill (2009b). In total, we have data on 3,635 cross-listings from 45 home markets in 32 host markets as at the end of 2006 (excluding OTC, investment funds and off-exchange listings). ${ }^{6}$ As we measure the activity between each home-host pair, we end up with a final sample of 1,408 home-host combinations $(45 \times 32-32)$.

\section{INSERT TABLE 1 HERE}

In Table 1, we report summary statistics on cross-listing activity as a home market (i.e. how many firms cross-list from a particular country) and as a host market (i.e. how many firms crosslist to a particular country). We also split our sample into developed (Panel A) and emerging (Panel B) markets as developing and emerging markets are affected by culture differently. ${ }^{7}$ Our sample contains 24 developed home markets. In total, these markets have 25,984 domestic listings and from these markets 3,015 firms cross-list $(82.8 \%$ of the cross-listed firms in our sample) (reported in first columns of Panel A). This, on average, leads to a cross-listing activity of about $12 \%$ from developed markets. Examining the developed markets more closely, we

\footnotetext{
${ }^{6}$ From the sample of Sarkissian and Schill (2009b) that includes 3,683 cross-listings from 73 home countries in 33 host markets we exclude home countries that contribute less than five cross-listings. We also exclude United Arab Emirates as a host country due to unavailability of investor protection data for this country.

${ }^{7}$ As shown by Sarkissian and Schill (2004), the role of cultural proximity is different between developed and emerging markets, a finding that is corroborated by Beugelsdijk and Frijns (2010) in their study on the impact of cultural distance on international asset allocation.
} 
observe that Canada has the greatest number of cross-listed firms (651) with 567 of those listed in a single market (the US). We also observe considerable numbers of cross-listings in the US, UK, Japan, Australia, Germany, the Netherlands, Israel, and France. However, as a percentage of domestic listings Ireland, the Netherlands and Luxembourg dominate with more cross-listings than domestic companies. ${ }^{8}$ The lowest percentage of cross-listings (1\%) is from Spain with just 40 cross-listings and 3,378 domestic firms. This is followed by Hong Kong and Singapore, with both $3 \%$.

The 21 emerging home markets (first columns of Panel B) hold 14,219 domestic listings from which 623 firms cross-list (17.2\% of our sample). This, on average, implies a cross-listing activity of about $4 \%$ from emerging markets and demonstrates a marked difference in the crosslisting activity of firms from developed or emerging markets. India has the most cross-listings (164), followed by South Africa (96). By percentage of domestic listings the largest countries are Hungary, Mexico, Argentina and South Africa. The lowest percentages of cross-listing are observed for Egypt, Malaysia and Thailand all with about 1\%.

Panel A of Table 1 also presents summary statistics for developed countries as the host markets (last columns). All 24 developed markets that are home to cross-listed firms also serve as a host market and collectively represent the host market for $99 \%$ of the cross-listed firms in our sample. Not surprisingly, the US is the most popular destination market for cross- listing with 1,404 , or nearly $40 \%$ of the sample. This is followed by the UK with 475 cross-listings. We further

\footnotetext{
${ }^{8}$ This is possible if firms cross-list in more than one host market. In this case, each cross-listing is counted in the number of cross-listings.
} 
observe significant cross-listings in both Switzerland and Luxembourg, traditional tax haven countries. As a percentage of the number of host country domestic firms, Luxembourg is the most popular destination market with $775 \%$, indicating it hosts considerably more firms than it has domestic listings (279 cross-listings compared with just 36 domestic listings). We also observe high percentages in the Netherlands, Belgium and Switzerland.

Panel B shows that far fewer emerging countries host cross-listings (last columns), and those firms that do cross-list into an emerging market tend to originate from another emerging market. Only eight countries in our emerging sample host cross-listed firms and, with the exception of South Africa, typically host fewer than five firms.

Table 1 further reveals that there is considerable clustering in cross-listings. From a home market perspective, we observe that most firms cross-list in a single host market. For instance, Canada, with 651 cross-listings, has 567 of these in the US (87\%). Likewise, Chilean and Israeli crosslistings are predominantly in the US. Indian, Irish, Polish and Egyptian firms cross-list primarily in the UK. We observe similar patterns for host markets, all firms cross-listing in Ireland are from the UK and 95\% of firms cross-listing in NZ are from Australia. Such strong clustering in the choice of destination market may indicate a familiarity bias in the choice of destination market.

\section{RESULTS}


Table 1 shows some evidence of clustering in the destination market for cross-listings. To more formally test for such clustering and whether the clustering could be attributable to culture, we use the Coval and Moskowitz (1999) Local Bias statistic. Coval and Moskowitz (1999) use this statistic to examine the role of geographic distance in explaining the home bias, i.e. to measure whether local investors have a bias towards geographically closer markets. This measure is also used by Sarkissian and Schill (2004) to examine the role of geographic distance in explaining the cross-listing decision. In this paper, we modify this statistic to test for a cultural proximity bias in the cross-listing decision. Specifically, we compute this statistic for home country $i$ as:

$$
B I A S_{i}=\sum_{j=1}^{J}\left(B_{j}-H_{i j}\right)\left(\frac{C D_{i j}}{C D_{i}^{B}}\right),
$$

where $H_{i j}$ is given as

$$
H_{i j}=\frac{C L_{i j}}{C L_{i}}
$$

with $C L_{i j}$ the number of cross-listings from home country $i$ to host country $j$ and $C L_{i}$ is the total number of companies with a listing in any other market. $B_{j}$ is the benchmark ratio of crosslistings (or the expected number of cross-listings if there is no proximity bias) to the total number 
of cross-listings from country $i$. To compute the benchmark weights $\left(B_{j}\right)$ we follow Coval and Moskowitz (1999) and Sarkissian and Schill (2004) and a use the market capitalization of each host country as a proportion of the market capitalization of all countries. $C D_{i j}$ is the cultural distance between country $i$ and $j$; and $C D_{i}^{B}$ is the value-weighted average cultural distance for home country $i$, i.e.,

$$
C D_{i}^{B}=\sum_{j=1}^{J} B_{j} C D_{i j} .
$$

Including this value-weighted average cultural distance benchmark in the calculation of the $B I A S$-statistics controls for the fact that some countries are, on average, more culturally distant from the rest of the world than other countries. A positive value for the BIAS statistic implies a positive cultural proximity bias, i.e. companies prefer to cross-list shares in countries that are culturally more similar, whereas a negative statistic implies a preference for countries that are more culturally distant.

INSERT TABLE 2 HERE

In Table 2, we report the results for the cultural proximity bias and the BIAS statistics for each country. The Actual column presents the weighted average cultural distance per country, or $C D_{i}$ $=\sum H_{i j} C D_{i j}$. The Benchmark column presents the weighted average cultural difference if cultural 
proximity plays no role and cross-listing occurred proportional to market capitalization. The difference between these two values indicates a cultural proximity bias. Specifically, where Actual is less than Benchmark, we get a positive BIAS statistic, indicating a preference for culturally similar cross-listing destinations.

For our developed home markets (the first columns of Panel A), we observe positive biases for all markets. In most cases, these biases are significant except for Israel, Japan, Luxembourg, the Netherlands and Singapore. New Zealand, Canada and Australia display the greatest bias, indicating a strong preference to invest in culturally similar markets. Overall, this suggests that firms prefer to cross-list in culturally similar markets.

The results for the developed countries as host markets (the last columns of Panel A) show mainly significant positive BIAS statistics, indicating that the companies choosing to cross-list into those markets come from culturally similar countries. For eight countries, however, we observe significantly negative BIAS statistics, suggesting that these markets are favoured by firms from culturally distant countries. These markets appear to be large financial centres, such as the US, UK, Germany and France, or tax havens such as Luxembourg and Switzerland. This suggests that some markets may be preferred for other reasons rather than cultural similarities, such as tax laws or market development reasons. 
Panel B of Table 2 presents the same analysis for our sample of emerging markets. The results for the emerging home markets suggest that cultural proximity plays little role in the choice of destination market. Only three countries have significant BIAS statistics, and two of those countries have negative statistics (Greece and Portugal), suggesting firms from those countries seek culturally disparate countries to list in. This finding is consistent with Beugelsdijk and Frijns (2010) who found that cultural distance plays no role in the foreign asset allocation decision of emerging market investors.

When we consider the emerging countries that host cross-listed firms, we see that they all have significant and positive BIAS statistics. The implication of this finding is that those firms seeking to cross-list in an emerging market seek culturally similar markets. However, these are likely to be restricted to predominantly emerging market firms, and as the result in Table 1 suggests, most emerging country cross-listings seek developed host markets.

\subsection{MULTIPLE REGRESSION ANALYSIS}

While the univariate analysis supports the hypothesis that cultural distance influences the crosslisting decision, we conduct regression analysis to ensure this relationship is not driven by other potential motivations. We estimate the following equation:

$$
\operatorname{DepVar}_{i j}=\alpha+\beta_{1} \text { CD }_{i j}+\gamma_{m} \text { Controls }_{i j m}+\varepsilon_{i j},
$$


where $D_{e p V a r}$ is one of three measures of cross-listing activity detailed below, $C D_{i j}$ is the cultural distance between the home country $i$ and host country $j$ calculated as in Equation (1), and Controls $s_{i j m}$ are various control variables.

\subsubsection{Dependent Variables}

We use three different measures of cross-listing activity in our empirical analysis. Our first measure is defined as the number of cross-listings between a specific pair of home and host countries, divided by the total number of domestic companies in the home country. Specifically,

$$
G_{i j}=\frac{C L_{i j}}{D C_{i}},
$$

where $C L_{i j}$ is the number of cross-listings from home $i$ to host $j$ and $D C_{i}$ is the total number of domestic companies listed in home country $i$. In essence, this measure computes the proportion of firms listing in a particular host market relative to all domestically listed firms and is the same measure employed in Sarkissian and Schill (2004).

Our second measure is defined as the number of cross-listings between a specific pair of home and host countries, divided by the total number of cross-listed companies from the home country, $H_{i j}$, as defined in Equation (3). Our final measure of cross-listing activity is a dummy variable 
that equals one if there are any cross-listings from home country $i$ to host country $j$, and zero otherwise.

\subsubsection{Control Variables}

While we postulate that cultural proximity between countries is a key factor in explaining the cross-listing decision, cultural proximity is likely to be correlated with other measures of proximity (see also Sarkissian and Schill, 2004). For example, countries may share a common language, be geographically close, and have similar legal systems, economic and industrial structures. To control for these potential explanations, we include several control variables in Equation (5).

First, we include a dummy for shared language. Shared language is often used as a measure for cultural proximity (see Sarkissian and Schill, 2004) and hence we include this control variable to examine whether our cultural distance measure is not just a proxy for common language. Based on the proximity preference argument (Sarkissian and Schill, 2004), we expect a positive relationship between shared language and cross-listing activity.

Second, we include a dummy for shared common law, which is one if both countries have common law legal systems. As common law is largely restricted to current and former members of the British Commonwealth, this measure captures a shared historical background and also controls for the superior investor protection prevalent in common law countries (see e.g. La Porta 
et al., 1998). Based on the proximity preference argument (Sarkissian and Schill, 2004), we again expect a positive relationship between shared common law and the proportion of crosslisting to a particular country.

Third, we include the log of the geographical distance in kilometres between the countries' main financial centres. ${ }^{9}$ Sarkissian and Schill (2004) show that geographic distance is negatively related to the proportion of cross-listing to a particular country. In addition, Grinblatt and Keloharju (2001) find that investors prefer stocks of firms that are headquartered in nearby locations, and Beugelsdijk and Frijns (2010) find that geographic distance has a negative impact on foreign asset allocation. Hence, we expect a negative relationship between geographic distance and the proportion of cross-listing to the host market.

The next two control variables are economic and industrial proximity as employed by Sarkissian and Schill (2004). Economic proximity is measured by the percentage of home country $i$ 's exports going to host country $j$. Industrial proximity is measured by the correlation of industry rankings between each pair of countries. For both variables, we expect a positive relationship.

Alexander et al. (1987) and Errunza and Miller (2000) argue that firms seek to cross-list to overcome market segmentation. Higher segmentation means markets are less likely to move together, and, from an investor's point of view, offer greater diversification benefits. We capture

${ }^{9}$ Geographic distances are the distances between the major financial centres of the countries calculated "as the crow flies”. Data source: the distance calculator from http://www.geobytes.com. 
the level of segmentation between markets by using the correlation between stock market index returns of host and home countries (see also Chan et al., 2005; Beugelsdijk and Frijns, 2010), calculated using monthly Datastream Total Market index returns in local currency over the past five years. The market segmentation hypothesis suggests a negative relationship between correlation and cross-listings.

To control for the legal bonding motivation for cross-listing posited by Doidge et al. (2004), we include a variable that measures the difference in the quality of the investor protection laws. Legal is calculated as the difference in investor protection between the host and home markets. We measure the investor protection of the home and host markets using the Anti-Self Dealing index of Djankov et al. (2008). We expect a positive relationship between the difference in legal environment and the extent of cross-listing activity.

We also control for liquidity motives for cross-listing (see Foerster and Karolyi, 1998) by including the log difference in market liquidity between the host and home markets. This difference is computed by the market turnover ratio (the value of the Datastream Total Market index's annual trading volume) divided by the index's market capitalization for the period 20022006. More liquid markets are expected to attract more cross-listings and hence we expect a positive relationship with cross-listing. 
More economically and financially developed markets are likely to offer greater benefits to cross-listing firms. We control for differences in economic development by employing Economic Development, computed as the log difference in GDP per capita in 2006 (measured in US\$) between the host and home market. Financial Development is computed as the log difference in the ratio of total stock market capitalization to GDP between host and home market. All values are from 2006, stock market capitalization values come from the World Federation of Exchanges' statistics, while country GDP is collected from UN statistics division. ${ }^{10}$ We expect that host countries with higher levels of economic and financial development relative to those of the home country attract larger number of foreign listings.

We further include an emerging home market indicator to capture significant differences in motivations to cross-list by companies from developed and from emerging markets. We follow Bekaert and Harvey (2000), Bekaert et al (2003) and Sarkissian and Schill (2004) to classify countries into developed and emerging.

Finally, we control for host market fixed effects, as some markets may be more attractive for cross-listings for institutional reasons, e.g. tax havens, large financial centres etc.

INSERT TABLE 3 HERE

\footnotetext{
${ }^{10}$ Available online at http://www.world-exchanges.org/statistics and http://unstats.un.org/unsd/databases.htm
} 
In Table 3, we report the results for Equation (5). We split Table 3 into three panels. Panel A reports the results for the $\log \left(G_{i j}\right)$ calculated as in Equation (6) as the dependent variable. In Panel B, the dependent variable is $\log \left(H_{i j}\right)$ calculated as in Equation (3). Because the dependent variables in Panels A and B are both left-censored, we estimate Equation (5) as a Tobit model. ${ }^{11}$ In Panel $\mathrm{C}$, we use the cross-listing dummy variable $D_{-} C L_{i j}$, which is set to one if there are any cross-listings between a particular host-home pair of countries. As the dependent variable is a dummy, we use a Probit model to estimate a probability of cross-listing from home $i$ to host $j$. For each measure of cross-listing activity, we estimate Equation (5) for the full sample and for developed and emerging home markets separately.

For the full sample, we observe some significance for the predicted relationship between our measures of cross-listing activity and cultural distance. We observe significance at the $10 \%$ level for one of the three dependent variables (cross-listing activity as a percentage of all home market firms and as a percentage of all cross-listed home market firms are insignificant). However, for the developed home countries sample we observe a strong and consistently significant negative relationship across all three dependent variables, indicating that cultural distance plays an important role in the cross-listing decision for firms from developed markets. This provides strong support for our hypothesis that firms prefer to cross-list into a market that is culturally similar to their home market. The results for the emerging markets are in line with the results in Table 2, which show that cultural distance is not a major determinant of the destination market.

\footnotetext{
${ }^{11}$ In many situations there are no cross-listings for a particular home-host pair of countries. In these situations the ratio of cross-listings is zero. In that value was set at .0001 and the natural $\log$ of that value was used as the dependent variable.
} 
In line with prior literature, we observe that other measures of proximity between home and host countries affect the distribution of cross-listings and the probability of cross-listing across host countries. More specifically, shared language, economic and industrial proximity and shared common law between home and host countries are positive determinants of cross-listing activity between the countries, while geographic distance is a negative determinant of the cross-listing activity. These results are in line with the findings of Sarkissian and Schill (2004) and further confirm the presence of a proximity bias in corporate decision to cross-list.

For our controls for other motivations and differences in market quality, we find that the correlation between stock market returns of the home and host markets is a positive significant determinant of the cross-listing activity. This is contrary to the predictions of the market segmentation theory of cross-listing. Possibly, higher market return correlations reflect higher levels of similarity between the stock markets. In this case, the positive sign of the correlation variable suggests further evidence for the proximity preference argument, i.e. companies tend to cross-list in markets that are driven by similar factors. An improvement in legal environment is a significant positive determinant of cross-listing destination for firms from developed markets while the relationship reverses for firms from emerging markets. Firms from emerging markets do not cross-list as frequently in foreign markets with stricter investor protection laws, possibly, due to prohibitively high disclosure and compliance costs. Furthermore, we find contrary evidence for both the liquidity and financial development variables. Other variables are not consistently significant. 


\subsection{ROBUSTNESS TEST}

To examine whether our conclusions on the role of cultural proximity in the decision to cross-list is sensitive to the choice the measure of cultural distance measure, we employ three alternative culture frameworks. First, we use the cultural value indices of Tang and Koveos (2008), which are an updated version of the Hofstede cultural value dimension scores. ${ }^{12}$ Second, we employ societal practices scores from the Global Leadership and Organizational Behavior Effectiveness (GLOBE) project (House et al, 2004). The GLOBE scores are based on survey data of almost 1,000 local organizations in 62 countries. The GLOBE project has expanded Hofstede's framework to nine dimensions of cultural values and practices to quantify national cultures: Performance Orientation, Assertiveness Orientation, Future Orientation, Humane Orientation, Institutional Collectivism, Family Collectivism, Gender Egalitarianism, Power Distance, and Uncertainty Avoidance. ${ }^{13}$ Although some of the cultural dimensions of Hofstede and the GLOBE are comparable, there are significant conceptual and methodological differences between these two cultural frameworks (e.g. see Smith, 2006). Finally, we use national cultural values from the World Value Survey (WVS). ${ }^{14,15}$ The World Value Survey has covered 97 societies and was conducted in five waves from 1981 to 2008. We follow Ahern et al. (2011) and calculate national averages to the responses of three survey questions focusing on Trust, Hierarchy and Egalitarianism. For each alternative cultural framework, we recalculate our measure of cultural distance as in Equation (1) and re-estimate Equation (5).

\footnotetext{
${ }^{12}$ Cultural scores from Tang and Koveos (2008) has been used in the literature, see for example Callen et al. (2010).

${ }^{13}$ The GLOBE cultural framework has been employed by, for example, Sarala and Vaara (2010).

${ }^{14}$ The World Value Survey data are available at http://www.worldvaluessurvey.org/

${ }^{15}$ The World Value Survey cultural framework has been used, for example, in Guiso et al. (2008) and Ahern et al. (2011).
} 


\section{INSERT TABLE 4 HERE}

Table 4 reports the estimation results. ${ }^{16}$ Coefficient estimates for all three alternative cultural distance variables are negative and statistically significant for the developed markets sub-sample. These results confirm our findings in Table 3 and show that larger cultural distance between the home and host countries results in less cross-listing activity between those countries. Table 4 confirms the insignificant role of cultural distance for emerging market firms, consistent with our earlier findings.

\section{CONCLUSION}

This paper extends the existing literature on international cross-listings in several ways. First, we extend the work of Sarkissian and Schill (2004) by examining the concept of cultural distance and the role it plays in the choice of destination market. Sarkissian and Schill (2004) measure cultural proximity in terms of common language and colonial ties, rough proxies of culture. We exploit more developed cultural frameworks such as Hofstede's (2001) Cultural Dimension scores to more accurately quantify the differences in culture between countries. After controlling for traditional motivations for cross-listing, we confirm the importance of cultural distance. Our findings demonstrate that a country's cultural values are important determinants of why companies from particular countries tend to cross-list more actively in particular host markets. More specifically, we show that the distribution of international cross-listings is significantly affected by the differences in cultural distance between country pairs. Our results are robust to

\footnotetext{
${ }^{16}$ To save space, estimates of control variables are not reported but were consistent with those reported in Table 3.
} 
alternative measures of cross-listing activity, estimation procedures, and alternative measures of cultural distance. Our results also highlight a notable dichotomy between the cross-listing motivations of emerging and developed market firms. In particular, we document the cultural proximity is an important consideration for cross-listing destination for companies from developed markets but appears to be dominated by other motivations for companies from emerging markets. Finally, this paper contributes to the literature on the role of culture in financial decision making. Our results highlight the importance of culture in corporate financing decisions and urge for further research in this area. 


\section{REFERENCES}

Aggarwal, R., Kearney, C. and Lucey, B. (2012). Gravity and culture in foreign portfolio investment. Journal of Banking \& Finance, 36 (2), 525-538.

Ahern, K., Daminelli, D. and Fracassi, C. (2012). Lost in translation? The effects of cultural values on mergers around the world. Journal of Financial Economics, forthcoming.

Alexander, G. J.,. Eun, C. S and Janakiramanan, S. (1987). Asset Pricing and Dual Listing on Foreign Capital Markets: A Note. The Journal of Finance, 42 (1), 151-158.

Amihud, Y. and Mendelson, H. (1986). Asset Pricing and the Bid-Ask Spread. Journal of Financial Economics, 17 (2), 223-249.

Anderson, C., Fedenia, M., Hirschey, M. and Skiba, H. (2011). Cultural influences on home bias and international diversification by institutional investors. Journal of Banking and Finance $35,916-934$.

Bancel, F. and Mittoo, C. R. (2001). European Managerial Perceptions of the Net Benefits of Foreign Stock Listings. European Financial Management, 7 (2), 213-236.

Barkema, H. G., Shenkar, O., Vermeulen, F. and Bell, J. H. J. (1997). Working Abroad, Working with Others: How Firms Learn to Operate International Joint Ventures. The Academy of Management Journal, 40 (2), 426-442.

Bekaert, G. and Harvey, C.R. (2000). Foreign Speculators and Emerging Equity Markets. The Journal of Finance 55 (2), 565-613.

Bekaert, G., Harvey, C.R. and Lundblad, C.T. (2003). Equity Market Liberalization in Emerging Markets. Journal of Financial Research 26 (3), 275-299.

Beugelsdijk, S. and Frijns, B. (2010). A cultural explanation of the foreign bias in international asset allocation. Journal of Banking and Finance 34, 2121-2131.

Callen, J.L., Morel, M. and Richerdson, G. (2010). Do culture and religion mitigate earnings management? Evidence from a cross-country analysis. International Journal of Disclosure and Governance, 8 (2), 103-121.

Chakrabarti, R., Gupta-Mukherjee, S. and Jayaraman, N. (2009). Mars-Venus marriages: Culture and cross-border M\&A. Journal of International Business Studies 40, 216-236.

Coffee, J. C. Jr. (1999). Future as History: The Prospects for Global Convergence in Corporate Governance and Its Implications. Northwestern University Law Review, 93 (3), 641-708.

Conn, R.L., Cosh A., Guest, P.M. and Hughes A. (2005). The impact on U.K. acquirers of domestic, cross-border, public and private acquisitions. Journal of Business Finance \& Accounting 32 (5/6), 815-870. 
Coval, J. and Moskowitz, T. (1999). Home Bias at Home: Local Equity Preference in Domestic Portfolios. Journal of Finance 54, 2045-2073.

Djankov, S., La Porta, R., Lopez-de-Silanes, F. and Shleifer, A. (2008). The Law and Economics of Self-Dealing. Journal of Financial Economics, 88, 430-465.

Doidge, C., Karolyi, G. A. and Stulz, R. M. (2004). Why Are Foreign Firms Listed in the U.S. Worth More? Journal of Financial Economics, 71 (2), 205-238.

Doidge, C., Karolyi, G. A. and Stulz, R. M. (2009). Has New York Become Less Competitive in Global Markets? Evaluating Foreign Listing Choice over Time. Journal of Financial Economics, 91 (3), 253-277.

Drogendijk, R. and Slangen, A. (2006). Hofstede, Schwartz, or Managerial Perceptions? The Effects of Different Cultural Distance Measures on Establishment Mode Choices by Multinational Enterprises. International Business Review, 15, 361-380.

Errunza, V. R. and D. P. Miller (2000). Market Segmentation and the Cost of Capital in International Equity Markets. The Journal of Financial and Quantitative Analysis, 35 (4), 577-600.

Fanto, J. and Karmel, R. (1997). A Report on the Attitudes of Foreign Companies Regarding a United States Listing. Stanford Journal of Law, Business and Finance, 3 (1), 51-75.

Fidrmuc, J., and Jacob, M. (2010). Culture, Agency Costs and Dividends. Journal of Comparative Economics, 38, 321-339.

Foerster, S. R. and. Karolyi, G. A (1993). International Listings of Stocks: The Case of Canada and the United States. Journal of International Business Studies, 24 (4), 763-784.

Foerster, S. R. and Karolyi, G. A. (1998). Multimarket Trading and Liquidity: A Transaction Data Analysis of Canada-United States Inter-Listings. Journal of International Financial Markets, Institutions and Money, 8 (3-4), 393-412.

Foerster, S. R. and Karolyi, G. A. (1999). The Effects of Market Segmentation and Investor Recognition on Asset Prices: Evidence from Foreign Stocks Listing in the United States. The Journal of Finance, 54 (3), 981-1013.

Fuerst, O. (1998). A Theoretical Analysis of the Investor Protection Regulations Argument for Global Listing of Stocks. Yale School of Management Working paper.

Grinblatt, M. and Keloharju, M. (2001). How distance, language, and culture influence stockholdings and trades. Journal of Finance 56, 1053-1073

Guiso, L., Sapienza, P. and Zingales, L. (2008). Trusting the Stock Market. Journal of Finance 63 (6), 2557-2600.

Hofstede, G. (2001). Culture's Consequences. Sage Publications: Beverly Hills, CA, $2^{\text {nd }}$ edition. 
House, R., Hanges, P.J., Javidan, M., Dorfman, P. and Gupta, V. (2004). GLOBE, cultures, leadership, and organizations: GLOBE study of 62 societies, Sage Publications: Newbury Park, CA.

Huberman, G. (2001). Familiarity breeds investment. Review of Financial Studies 14, 659-680.

King, M. R. and Mittoo, U. R. (2007). What Companies Need to Know About International Cross-Listing. Journal of Applied Corporate Finance, 19 (4), 60-74.

Kirkman, B., Lowe, K. and Gibson, C. (2006). A quarter century of Culture's Consequences: A review of empirical research incorporating Hofstede's cultural values framework. Journal of International Business Studies 37, 285-320.

Kogut, B. and Singh, H. (1988). The effect of national culture on the choice of entry mode. Journal of International Business Studies, 19, 411-432.

La Porta, R., Lopez-de-Silanes, F., Shleifer, A. and Vishny, R. (1998). Law and finance. Journal of Political Economy, 106, 1113-1155

Merton, R. C. (1987). A Simple Model of Capital Market Equilibrium with Incomplete Information. The Journal of Finance, 42 (3), 483-510.

Miller, D. P. (1999). The Market Reaction to International Cross-Listings: Evidence from Depositary Receipts. Journal of Financial Economics, 51 (1), 103-123.

Mittoo, U. R. (2003). Globalization and the Value of United States Listing: Revisiting Canadian Evidence. Journal of Banking and Finance, 27 (9), 1629-1661.

Pagano, M., A. A. Roell, and J. Zechner (2002). The Geography of Equity Listing: Why Do Companies List Abroad? The Journal of Finance, 57 (6), 2651-2694.

Sarala, R.M. and Vaara, E. (2010). Cultural differences, convergence, and crossvergence as explanations of knowledge transfer in international acquisitions. Journal of International Business Studies 41, 1365-1390.

Sarkissian, S. and M. J. Schill (2004). The Overseas Listing Decision: New Evidence of Proximity Preference. Review of Financial Studies, 17 (3), 769-809.

Sarkissian, S. and M. J. Schill (2009a). Are There Permanent Valuation Gains to Overseas Listing? Review of Financial Studies, 22 (1), 371-412.

Sarkissian, S. and M. J. Schill (2009b). Cross Listing Waves and the Search for Value Gains. SSRN working paper.

Shenkar, O. (2001). Cultural distance revisited: Towards a more rigorous conceptualization and measurement of cultural differences. Journal of International Business Studies 32, 519-535.

Siegel, J.I., Licht, N. and Schwartz, S.H. (2008). Egalitarianism, cultural distance, and FDI: A new approach. SSRN Working paper. 
Siegel, J.I., Licht, N. and Schwartz, S.H. (2010). Egalitarianism and International Investment. SSRN Working paper.

Smith, P.B. (2006). When elephants fight, the grass gets trampled: the GLOBE and Hofstede projects. Journal of International Business Studies 37, 915-921.

Stapleton, R. C. and Subrahmanyam, M. G. (1977). Market Imperfections, Capital Market Equilibrium and Corporate Finance. The Journal of Finance, 32 (2), 307-319.

Stulz, R. M. (1999). Globalization, Corporate Finance, and the Cost of Capital. Journal of Applied Corporate Finance, 12 (3), 8-25.

Tang, L. and Koveos, P. (2008). A framework to update Hofstede's value indices: Economic dynamics and institutional stability. Journal of International Business Studies 39, 10451063. 
Table 1. Sample Description

\begin{tabular}{|c|c|c|c|c|c|c|c|c|}
\hline \multirow[b]{2}{*}{ Country } & \multicolumn{4}{|c|}{ As Home Market } & \multicolumn{4}{|c|}{ As Host Market } \\
\hline & $D C_{i}$ & $C L_{i}$ & $C L_{i} / D C_{i}$ & $\operatorname{Max} C l_{i j}$ & $D C_{j}$ & $\sum C L_{i j}$ & $\sum C L_{i j} / D C_{j}$ & $\operatorname{Max} C l_{i j}$ \\
\hline \multicolumn{9}{|c|}{ PANEL A: DEVELOPED MARKETS } \\
\hline Australia & 1,751 & 172 & 0.10 & 87 & 1,751 & 60 & 0.034 & 26 \\
\hline Austria & 96 & 12 & 0.13 & 6 & 96 & 34 & 0.354 & 19 \\
\hline Belgium & 137 & 34 & 0.25 & 9 & 137 & 129 & 0.942 & 35 \\
\hline Canada & 3,790 & 651 & 0.17 & 567 & 3,790 & 95 & 0.025 & 62 \\
\hline Denmark & 190 & 13 & 0.07 & 7 & 190 & 10 & 0.053 & 7 \\
\hline Finland & 136 & 19 & 0.14 & 6 & 136 & 2 & 0.015 & 2 \\
\hline France & 642 & 109 & 0.17 & 37 & 642 & 206 & 0.321 & 45 \\
\hline Germany & 656 & 151 & 0.23 & 29 & 656 & 193 & 0.294 & 54 \\
\hline Hong Kong & 1,165 & 38 & 0.03 & 17 & 1,165 & 2 & 0.002 & 1 \\
\hline Ireland & 59 & 75 & 1.27 & 55 & 59 & 17 & 0.288 & 17 \\
\hline Israel & 606 & 149 & 0.25 & 124 & 606 & 5 & 0.008 & 4 \\
\hline Italy & 284 & 37 & 0.13 & 17 & 284 & 23 & 0.081 & 9 \\
\hline Japan & 2,857 & 234 & 0.08 & 54 & 2,857 & 138 & 0.048 & 80 \\
\hline Luxembourg & 36 & 40 & 1.11 & 9 & 36 & 279 & 7.750 & 121 \\
\hline Netherlands & 128 & 151 & 1.18 & 42 & 128 & 159 & 1.242 & 77 \\
\hline New Zealand & 151 & 33 & 0.22 & 26 & 151 & 91 & 0.603 & 87 \\
\hline Norway & 195 & 27 & 0.14 & 12 & 195 & 21 & 0.108 & 5 \\
\hline Singapore & 461 & 14 & 0.03 & 6 & 461 & 44 & 0.095 & 9 \\
\hline Spain & 3,378 & 40 & 0.01 & 11 & 3,378 & 5 & 0.001 & 2 \\
\hline Sweden & 276 & 60 & 0.22 & 15 & 276 & 32 & 0.116 & 8 \\
\hline Switzerland & 256 & 51 & 0.20 & 15 & 256 & 175 & 0.684 & 71 \\
\hline Taiwan & 688 & 69 & 0.10 & 47 & 688 & 3 & 0.004 & 2 \\
\hline UK & 2,913 & 285 & 0.10 & 143 & 2,913 & 475 & 0.163 & 104 \\
\hline US & 5,133 & 551 & 0.11 & 104 & 5,133 & 1,404 & 0.274 & 567 \\
\hline All developed markets & 25,984 & 3,015 & 0.12 & 567 & 25,984 & 3,602 & 0.139 & 567 \\
\hline \multicolumn{9}{|c|}{ PANEL B: EMERGING MARKETS } \\
\hline Argentina & 101 & 28 & 0.28 & 20 & 101 & 1 & 0.01 & 1 \\
\hline Brazil & 347 & 40 & 0.12 & 34 & 347 & 3 & 0.009 & 1 \\
\hline Chile & 244 & 26 & 0.11 & 25 & & & & \\
\hline China & 1,421 & 37 & 0.03 & 29 & & & & \\
\hline Colombia & 94 & 5 & 0.05 & 3 & & & & \\
\hline Czech Rep & 26 & 5 & 0.19 & 4 & & & & \\
\hline Egypt & 595 & 7 & 0.01 & 7 & & & & \\
\hline Greece & 288 & 25 & 0.09 & 10 & & & & \\
\hline Hungary & 41 & 14 & 0.34 & 5 & & & & \\
\hline India & 5,952 & 164 & 0.03 & 121 & & & & \\
\hline Indonesia & 344 & 9 & 0.03 & 4 & & & & \\
\hline Korea & 1,689 & 56 & 0.03 & 22 & & & & \\
\hline Malaysia & 1,021 & 7 & 0.01 & 4 & 1,021 & 3 & 0.003 & 3 \\
\hline Mexico & 132 & 40 & 0.30 & 40 & 132 & 1 & 0.008 & 1 \\
\hline Philippines & 238 & 11 & 0.05 & 5 & & & & \\
\hline Peru & - & - & - & - & 189 & 1 & 0.005 & 1 \\
\hline Poland & 253 & 12 & 0.05 & 11 & 253 & 5 & 0.02 & 2 \\
\hline Portugal & 47 & 7 & 0.15 & 4 & 47 & 2 & 0.043 & 2 \\
\hline Russia & 193 & 16 & 0.08 & 10 & & & & \\
\hline South Africa & 359 & 96 & 0.27 & 35 & 359 & 17 & 0.047 & 7 \\
\hline Thailand & 518 & 6 & 0.01 & 2 & & & & \\
\hline Turkey & 316 & 12 & 0.04 & 9 & & & & \\
\hline All emerging markets & 14,219 & 623 & 0.04 & 121 & 2,449 & 33 & 0.018 & 7 \\
\hline
\end{tabular}


The table reports summary statistics on cross-listing activity as of December 2006 for each sample country as a home market and as a host market, in Panel $\mathrm{A}$ for developed markets and in Panel $\mathrm{B}$ for emerging markets. $D C_{i}$ is the total number of domestic listed companies in home country $i . C L_{i}$ is the total number of cross-listings from home country $i$. $C L_{i j}$ is the number of cross-listings from the home country $i$ to the host country $j$. 
Table 2. Coval-Moskowitz Test for Cultural Bias of Cross-listings

\begin{tabular}{|c|c|c|c|c|c|c|}
\hline & \multicolumn{3}{|c|}{ "Cultural Distance by Home Market } & \multicolumn{3}{|c|}{ "Cultural Distance by Host Market } \\
\hline & Actual & Benchmark & $B I A S_{i}$ & Actual & Benchmark & $B I A S_{i}$ \\
\hline \multicolumn{7}{|c|}{ PANEL A: DEVELOPED MARKETS } \\
\hline Australia & 0.624 & 0.981 & $36.44 \% * * *$ & 2.418 & 1.096 & $-1.21 \% * * *$ \\
\hline Austria & 1.469 & 1.832 & $19.81 \% * *$ & 0.599 & 1.891 & $0.68 \% * * *$ \\
\hline Belgium & 1.354 & 1.694 & $20.06 \% * *$ & 1.389 & 1.726 & $0.2 \% * * *$ \\
\hline Canada & 0.581 & 1.07 & $45.73 \% * * *$ & 0.739 & 1.157 & $0.36 \% * * *$ \\
\hline Denmark & 1.826 & 2.31 & $20.98 \% * * *$ & 0.255 & 2.358 & $0.89 \% * * *$ \\
\hline Finland & 1.474 & 1.742 & $15.35 \% * * *$ & 0.04 & 1.774 & $0.98 \% * * *$ \\
\hline France & 1.55 & 1.764 & $12.13 \% * * *$ & 2.807 & 1.783 & $-0.57 \% * * *$ \\
\hline Germany & 1.045 & 1.201 & $12.96 \% * *$ & 2.662 & 1.27 & $-1.1 \% * * *$ \\
\hline Hong Kong & 1.946 & 2.201 & $11.55 \% * *$ & 0.011 & 2.12 & $1 \% * * *$ \\
\hline Ireland & 0.687 & 1.301 & $47.21 \% * * *$ & 0.038 & 1.375 & $0.97 \% * * *$ \\
\hline Israel & 1.84 & 1.883 & $2.28 \%$ & 0.02 & 1.925 & $0.99 \% * * *$ \\
\hline Italy & 1.132 & 1.273 & $11.13 \% * *$ & 0.336 & 1.338 & $0.75 \% * * *$ \\
\hline Japan & 2.149 & 2.259 & $4.90 \%$ & 1.843 & 2.281 & $0.19 \% * * *$ \\
\hline Luxembourg & 1.288 & 1.325 & $2.81 \%$ & 8.098 & 1.361 & $-4.95 \% * * *$ \\
\hline Netherlands & 1.935 & 2.02 & $4.18 \%$ & 2.51 & 2.065 & $-0.22 \% * * *$ \\
\hline New Zealand & 0.609 & 1.225 & $50.31 \% * * *$ & 0.308 & 1.319 & $0.77 \% * * *$ \\
\hline Norway & 1.881 & 2.232 & $15.72 \% * * *$ & 0.444 & 2.263 & $0.8 \% * * *$ \\
\hline Singapore & 2.578 & 2.642 & $2.43 \%$ & 1.896 & 2.561 & $0.26 \% * * *$ \\
\hline Spain & 1.598 & 1.772 & $9.82 \% * *$ & 0.087 & 1.764 & $0.95 \% * * *$ \\
\hline Sweden & 2.003 & 2.448 & $18.19 \% * * *$ & 0.94 & 2.478 & $0.62 \% * * *$ \\
\hline Switzerland & 1.066 & 1.175 & $9.24 \% * *$ & 1.564 & 1.248 & $-0.25 \% * * *$ \\
\hline Taiwan & 1.809 & 2.206 & $17.98 \% *$ & 0.348 & 2.134 & $0.84 \% * * *$ \\
\hline UK & 1.031 & 1.207 & $14.63 \% * * *$ & 20.484 & 1.322 & $-14.5 \% * * *$ \\
\hline United States & 1.251 & 1.518 & $17.57 \% * * *$ & 30.476 & 1.714 & $-16.78 \% * * *$ \\
\hline \multicolumn{7}{|c|}{ PANEL B: EMERGING MARKETS } \\
\hline Argentina & 1.625 & 1.649 & $1.43 \%$ & 0.015 & 1.648 & $0.99 \% * * *$ \\
\hline Brazil & 2.019 & 1.868 & $-8.12 \%$ & 0.049 & 1.823 & $0.97 \% * * *$ \\
\hline Chile & 2.806 & 2.446 & $-14.73 \%$ & & & \\
\hline China & 2.5 & 2.382 & $-4.92 \%$ & & & \\
\hline Colombia & 2.119 & 2.336 & $9.26 \%$ & & & \\
\hline Czech Rep & 1.494 & 1.371 & $-9.01 \%$ & & & \\
\hline Egypt & 2.41 & 1.938 & $-24.38 \%$ & & & \\
\hline Greece & 2.801 & 2.317 & $-20.87 \% * * *$ & & & \\
\hline Hungary & 1.54 & 1.621 & $4.96 \%$ & & & \\
\hline India & 1.625 & 1.771 & $8.26 \%$ & & & \\
\hline Indonesia & 2.591 & 2.421 & $-7.04 \%$ & & & \\
\hline Korea & 2.323 & 2.353 & $1.28 \%$ & & & \\
\hline Malaysia & 2.757 & 2.719 & $-1.37 \%$ & 0.032 & 2.623 & $0.99 \% * * *$ \\
\hline Mexico & 2.549 & 2.2 & $-15.83 \%$ & 0.005 & 2.148 & $1 \% * * *$ \\
\hline Peru & - & - & - & 0.005 & 2.335 & $1 \% * * *$ \\
\hline Philippines & 2.16 & 2.317 & $6.75 \%$ & & & \\
\hline Poland & 2.13 & 1.738 & $-22.54 \%$ & 0.441 & 1.747 & $0.75 \% * * *$ \\
\hline Portugal & 2.81 & 2.567 & $-9.47 \% *$ & 0.051 & 2.513 & $0.98 \% * * *$ \\
\hline Russia & 3.093 & 2.577 & $-20.03 \%$ & & & \\
\hline South Africa & 1.035 & 1.137 & $8.94 \%$ & 0.087 & 1.179 & $0.93 \% * * *$ \\
\hline Thailand & 1.622 & 2.272 & $28.61 \% * * *$ & & & \\
\hline Turkey & 2.277 & 1.955 & $-16.48 \%$ & & & \\
\hline
\end{tabular}


The table reports the results of the test for bias in cultural distance of cross-listings for home and host markets using methodology of Coval and Moskowtiz (1999), in Panel A for developed markets and in Panel B for emerging markets. Actual is the weighted average cultural distance per country: $C D_{i}=\sum H_{i j} C D_{i j}$, where $H_{i j}$ is the ratio of crosslistings from home country $i$ to host country $j$ to the total number of cross-listings from country $i$ and $C D_{i j}$ is the cultural distance between country $i$ and $j$ calculated as the Euclidean distance with Hofstede cultural scores. Benchmark is the benchmark-weighted average cultural distance for home country $i$ : $C D_{i}^{B}=\sum_{j=1}^{J} B_{j} C D_{i j}$, where $B_{j}$ is the benchmark ratio of cross-listings to the total number of cross-listings from country $i$, calculated using the proportion of the total market capitalization of a country in the total market capitalization of all countries. The $B I A S$-statistics is computed as follows: $B I A S_{i}=\sum_{j=1}^{J}\left(B_{j}-H_{i j}\right)\left(\frac{C D_{i j}}{C D_{i}^{B}}\right)$. 
Table 3. Regression analysis: Cultural Distance and Cross-listing Decision

\begin{tabular}{|c|c|c|c|c|c|c|c|c|c|c|}
\hline & \multirow{2}{*}{$\begin{array}{l}\text { Exp. } \\
\text { sign }\end{array}$} & \multicolumn{3}{|c|}{ (A) Tobit Model: $\ln \left(G_{i j}\right),\left(G_{i j}=C L_{i j} / D C_{i}\right)$} & \multicolumn{3}{|c|}{ (B) Tobit Model: $\ln \left(H_{i j}\right),\left(H_{i j}=C L_{i j} / C L_{i}\right)$} & \multicolumn{3}{|c|}{ (C) Probit Model: $D_{-} C L_{i j}$} \\
\hline & & $\begin{array}{c}\text { All } \\
\text { Countries }\end{array}$ & $\begin{array}{l}\text { Developed } \\
\text { Markets }\end{array}$ & $\begin{array}{c}\text { Emerging } \\
\text { Markets }\end{array}$ & $\begin{array}{c}\text { All } \\
\text { Countries }\end{array}$ & $\begin{array}{c}\text { Developed } \\
\text { Markets }\end{array}$ & $\begin{array}{l}\text { Emerging } \\
\text { Markets }\end{array}$ & $\begin{array}{c}\text { All } \\
\text { Countries }\end{array}$ & $\begin{array}{c}\text { Developed } \\
\text { Markets }\end{array}$ & $\begin{array}{l}\text { Emerging } \\
\text { Markets }\end{array}$ \\
\hline $\begin{array}{l}\text { Hofstede cultural } \\
\text { distance }\end{array}$ & - & $\begin{array}{c}-0.44 \\
(-1.63)\end{array}$ & $\begin{array}{c}-0.67 * * * \\
(-2.60)\end{array}$ & $\begin{array}{c}-0.95 \\
(-1.11)\end{array}$ & $\begin{array}{c}-0.59 \\
(-1.49)\end{array}$ & $\begin{array}{c}-1.07 * * * \\
(-2.84)\end{array}$ & $\begin{array}{c}-0.88 \\
(-0.67)\end{array}$ & $\begin{array}{l}-0.16^{*} \\
(-1.75)\end{array}$ & $\begin{array}{c}-0.24 * * \\
(-2.09)\end{array}$ & $\begin{array}{c}0.06 \\
(0.27)\end{array}$ \\
\hline Language & + & $\begin{array}{l}1.08 * * \\
(2.08)\end{array}$ & $\begin{array}{c}0.79 \\
(1.44)\end{array}$ & $\begin{array}{c}1.40 \\
(0.80)\end{array}$ & $\begin{array}{c}1.24 \\
(1.55)\end{array}$ & $\begin{array}{c}1.01 \\
(1.26)\end{array}$ & $\begin{array}{c}0.83 \\
(0.28)\end{array}$ & $\begin{array}{l}0.37^{*} \\
(1.81)\end{array}$ & $\begin{array}{c}0.36 \\
(1.39)\end{array}$ & $\begin{array}{c}0.32 \\
(0.78)\end{array}$ \\
\hline Common law & + & $\begin{array}{l}1.17^{*} \\
(1.75)\end{array}$ & $\begin{array}{c}2.63 * * * \\
(3.55)\end{array}$ & $\begin{array}{l}-3.05^{* *} \\
(-2.16)\end{array}$ & $\begin{array}{l}1.87^{*} \\
(1.83)\end{array}$ & $\begin{array}{c}3.51 * * * \\
(3.28)\end{array}$ & $\begin{array}{l}-3.43 \\
(-1.48)\end{array}$ & $\begin{array}{l}0.44^{*} \\
(1.76)\end{array}$ & $\begin{array}{c}0.86^{* * * *} \\
(2.70)\end{array}$ & $\begin{array}{l}-0.05 \\
(-0.10)\end{array}$ \\
\hline Geo distance & - & $\begin{array}{c}-0.96^{* * *} \\
(-5.25)\end{array}$ & $\begin{array}{c}-0.67 * * * \\
(-3.00)\end{array}$ & $\begin{array}{c}-1.89 * * * \\
(-4.03)\end{array}$ & $\begin{array}{c}-1.37 * * * \\
(-4.89)\end{array}$ & $\begin{array}{r}-0.82^{* *} \\
(-2.50)\end{array}$ & $\begin{array}{c}-3.05^{* * *} \\
(-4.25)\end{array}$ & $\begin{array}{c}-0.18 * * * \\
(-2.61)\end{array}$ & $\begin{array}{c}0.04 \\
(0.41)\end{array}$ & $\begin{array}{r}-0.30^{* *} \\
(-2.48)\end{array}$ \\
\hline Econ prox & + & $\begin{array}{l}0.06^{*} \\
(1.90)\end{array}$ & $\begin{array}{c}0.06 \\
(1.05)\end{array}$ & $\begin{array}{l}0.07^{*} \\
(1.96)\end{array}$ & $\begin{array}{l}0.09 * \\
(1.70)\end{array}$ & $\begin{array}{c}0.07 \\
(0.93)\end{array}$ & $\begin{array}{c}0.10 \\
(1.61)\end{array}$ & $\begin{array}{c}0.05^{* * *} \\
(3.48)\end{array}$ & $\begin{array}{c}0.15^{* * *} \\
(3.91)\end{array}$ & $\begin{array}{r}0.04 * * \\
(2.09)\end{array}$ \\
\hline Industrial prox & + & $\begin{array}{c}2.97 * * * \\
(4.52)\end{array}$ & $\begin{array}{c}2.83 * * * \\
(4.45)\end{array}$ & $\begin{array}{l}3.33 * * \\
(2.19)\end{array}$ & $\begin{array}{c}4.06^{* * *} \\
(4.15)\end{array}$ & $\begin{array}{c}3.75^{* * *} \\
(3.95)\end{array}$ & $\begin{array}{r}4.76^{* *} \\
(2.06)\end{array}$ & $\begin{array}{c}0.90^{* * *} \\
(4.12)\end{array}$ & $\begin{array}{c}1.10^{* * *} \\
(4.12)\end{array}$ & $\begin{array}{c}0.62 \\
(1.57)\end{array}$ \\
\hline Correlation & - & $\begin{array}{c}1.68 * * * \\
(2.86)\end{array}$ & $\begin{array}{l}1.90 * * \\
(2.34)\end{array}$ & $\begin{array}{c}0.62 \\
(0.58)\end{array}$ & $\begin{array}{c}2.56^{* * *} \\
(2.96)\end{array}$ & $\begin{array}{c}3.20^{* * *} \\
(2.62)\end{array}$ & $\begin{array}{c}0.82 \\
(0.51)\end{array}$ & $\begin{array}{c}0.67 * * * \\
(3.39)\end{array}$ & $\begin{array}{c}1.06^{* * * *} \\
(3.06)\end{array}$ & $\begin{array}{r}0.57 * * \\
(2.28)\end{array}$ \\
\hline Legal & + & $\begin{array}{c}0.35 \\
(0.85)\end{array}$ & $\begin{array}{l}1.16^{* *} \\
(2.57)\end{array}$ & $\begin{array}{l}-1.78^{*} \\
(-1.83)\end{array}$ & $\begin{array}{c}-0.01 \\
(-0.02)\end{array}$ & $\begin{array}{c}1.06^{*} \\
(1.71)\end{array}$ & $\begin{array}{c}-3.06^{* *} \\
(-2.06)\end{array}$ & $\begin{array}{c}0.07 \\
(0.49)\end{array}$ & $\begin{array}{c}0.37 * * \\
(2.05)\end{array}$ & $\begin{array}{c}0.02 \\
(0.09)\end{array}$ \\
\hline Liquidity & + & $\begin{array}{l}-0.16 \\
(-1.02)\end{array}$ & $\begin{array}{c}-0.34 * * \\
(-2.21)\end{array}$ & $\begin{array}{c}0.41 \\
(1.02)\end{array}$ & $\begin{array}{l}-0.41^{*} \\
(-1.83)\end{array}$ & $\begin{array}{c}-0.63 * * * \\
(-2.94)\end{array}$ & $\begin{array}{c}0.41 \\
(0.65)\end{array}$ & $\begin{array}{l}-0.10^{*} \\
(-1.90)\end{array}$ & $\begin{array}{c}-0.13^{* *} \\
(-2.25)\end{array}$ & $\begin{array}{c}0.04 \\
(0.40)\end{array}$ \\
\hline Fin development & + & $\begin{array}{c}-0.61 * * \\
(-2.42)\end{array}$ & $\begin{array}{c}-0.53^{* *} \\
(-2.12)\end{array}$ & $\begin{array}{c}-1.47 * * \\
(-2.36)\end{array}$ & $\begin{array}{c}-0.94 * * * \\
(-2.61)\end{array}$ & $\begin{array}{c}-0.90^{* *} \\
(-2.48)\end{array}$ & $\begin{array}{c}-2.27 * * \\
(-2.50)\end{array}$ & $\begin{array}{c}-0.21^{* * *} \\
(-2.62)\end{array}$ & $\begin{array}{c}-0.26^{* * *} \\
(-2.67)\end{array}$ & $\begin{array}{c}-0.26^{* *} \\
(-2.11)\end{array}$ \\
\hline Econ development & + & $\begin{array}{c}-0.14 \\
(-0.47)\end{array}$ & $\begin{array}{l}-1.13 * \\
(-1.88)\end{array}$ & $\begin{array}{c}-0.52 \\
(-1.11)\end{array}$ & $\begin{array}{c}-0.02 \\
(-0.04)\end{array}$ & $\begin{array}{l}-1.02 \\
(-1.17)\end{array}$ & $\begin{array}{c}-0.58 \\
(-0.83)\end{array}$ & $\begin{array}{c}-0.00 \\
(-0.01)\end{array}$ & $\begin{array}{c}-0.23 \\
(-0.98)\end{array}$ & $\begin{array}{c}0.07 \\
(0.61)\end{array}$ \\
\hline Home EM & - & $\begin{array}{l}-1.30^{*} \\
(-1.96)\end{array}$ & & & $\begin{array}{c}-1.99^{* *} \\
(-2.01)\end{array}$ & & & $\begin{array}{c}-0.54 * * \\
(-2.54)\end{array}$ & & \\
\hline $\begin{array}{l}\text { Host country fixed } \\
\text { effects }\end{array}$ & & YES & YES & YES & YES & YES & YES & YES & YES & YES \\
\hline $\begin{array}{l}\text { Observations } \\
\text { Left-censored obs }\end{array}$ & & $\begin{array}{l}1,408 \\
1,112\end{array}$ & $\begin{array}{l}744 \\
522\end{array}$ & $\begin{array}{l}664 \\
590\end{array}$ & $\begin{array}{l}1,408 \\
1112\end{array}$ & $\begin{array}{l}744 \\
522\end{array}$ & $\begin{array}{l}664 \\
590\end{array}$ & 1,408 & 744 & 664 \\
\hline $\begin{array}{l}\text { Left-censored obs. } \\
\text { Log likelihood }\end{array}$ & & $\begin{array}{c}1,112 \\
-1061.2\end{array}$ & $\begin{array}{c}522 \\
-717.9\end{array}$ & $\begin{array}{c}590 \\
-276.9\end{array}$ & -1185.4 & -806.6 & -309.2 & -385.0 & -244.1 & -113.1 \\
\hline
\end{tabular}

The table report regression estimation results using the sample of cross-listings from 45 home markets in 32 host markets as of December 2006 . Panel A reports results for the dependant variable the $\log G_{i j}$ defined as the number of cross-listings from home country $\mathrm{i}$ in host country $\mathrm{j}$, divided by the total number of 
domestic companies in the home country i: $G_{i j}=C L_{i j} / D C_{i}$. Panel B reports results for the dependant variable the log $H_{i j}$ defined as the number of cross-listings listings from home country $\mathrm{i}$ in host country $\mathrm{j}$, divided by the total number of cross-listed companies from the home country $\mathrm{i}: H_{i j}=C L_{i j} / C L_{i}$. Both Panel $\mathrm{A}$ and $\mathrm{B}$ report Tobit model estimation results. Panel $\mathrm{C}$ reports results for the dependant variable $D C L_{i j}$, a dummy variable set to one if there are any cross-listings from home country i in host country j. Panel $\mathrm{C}$ reports Probit model estimation results. For each dependent variable the results are reported for the full sample, for developed and emerging home markets. Hofstede cultural distance is the cultural distance between the home country $i$ and host country $j$ calculated as the Euclidean Distance using Hofstede's (2001) culture scores. Language is a dummy variable set to one if the home country $i$ and host country $j$ share an official language. Common law is a dummy variable set to one if both home country $i$ and host country $j$ have common law legal systems. Geo distance is the log of the geographical distance in kilometres between the main financial centres of the home country $i$ and host country $j$. Econ prox is the measure of economic proximity from Sarkissian and Schill (2004) defined as the percentage of the home country $i$ 's export going to the host country $j$. Industrial prox is the measure of industrial proximity from Sarkissian and Schill (2004) defined as the correlation of industry rankings between the home country $i$ and host country $j$. Correlation is the correlation between stock market index returns of host and home countries, calculated using monthly Datastream Total Market index returns in local currency over the past five years. Legal is the difference in investor protection between the host and home countries, calculated using the Anti-Self Dealing index of Djankov et al. (2008). Liquidity is the log difference in the market turnover ratios between the host and home markets, computed as the value of the Datastream Total Market index's annual trading volume divided by the index's market capitalization for the period 2002-2006. Fin development is the log difference in the ratio of total stock market capitalization (data obtained from the World Federation of Exchanges' statistics) to GDP (data collected from UN statistics division) between host and home markets in 2006. Econ development is the log difference in GDP per capita in 2006 (measured in US\$) between the host and home countries. Home EM is a dummy variable set to one if home country $i$ is an emerging market. 
Table 4. Alternative Measures of Cultural Distance

\begin{tabular}{|c|c|c|c|c|c|c|c|c|c|}
\hline & \multicolumn{3}{|c|}{ (A) Tobit Model: $\ln \left(G_{i j}\right),\left(G_{i j}=C L_{i j} / D C_{i}\right)$} & \multicolumn{3}{|c|}{ (B) Tobit Model: $\ln \left(H_{i j}\right),\left(H_{i j}=C L_{i j} / C L_{i}\right)$} & \multicolumn{3}{|c|}{ (C) Probit Model: $D_{-} C L_{i j}$} \\
\hline & $\begin{array}{c}\text { All } \\
\text { Countries } \\
\end{array}$ & $\begin{array}{c}\text { Developed } \\
\text { Markets }\end{array}$ & Emerging Markets & $\begin{array}{c}\text { All } \\
\text { Countries } \\
\end{array}$ & $\begin{array}{c}\text { Developed } \\
\text { Markets }\end{array}$ & $\begin{array}{c}\text { Emerging } \\
\text { Markets }\end{array}$ & $\begin{array}{c}\text { All } \\
\text { Countries } \\
\end{array}$ & $\begin{array}{c}\text { Developed } \\
\text { Markets }\end{array}$ & $\begin{array}{c}\text { Emerging } \\
\text { Markets }\end{array}$ \\
\hline \multicolumn{10}{|c|}{ Panel I. Tang and Koveos's Cultural Distance } \\
\hline $\begin{array}{l}\text { Tang Koveos } \\
\text { cultural distance }\end{array}$ & $\begin{array}{c}-0.07 \\
(-0.36)\end{array}$ & $\begin{array}{c}-0.51^{* * *} \\
(-2.64)\end{array}$ & $\begin{array}{c}-0.47 \\
(-0.58)\end{array}$ & $\begin{array}{c}-0.05 \\
(-0.18)\end{array}$ & $\begin{array}{c}-0.81 * * * \\
(-2.78)\end{array}$ & $\begin{array}{c}-0.14 \\
(-0.11)\end{array}$ & $\begin{array}{c}0.00 \\
(0.00)\end{array}$ & $\begin{array}{c}-0.10 \\
(-1.02)\end{array}$ & $\begin{array}{c}0.33 \\
(1.48)\end{array}$ \\
\hline Observations & 1,044 & 616 & 428 & 1,044 & 616 & 428 & 1,044 & 616 & 428 \\
\hline Left censored obs. & 800 & 419 & 381 & 800 & 419 & 381 & & & \\
\hline Log likelihood & -817.1 & -597.8 & -166.5 & -926.7 & -684.4 & -186.8 & -280.9 & -195.9 & -71.6 \\
\hline \multicolumn{10}{|c|}{ Panel II. GLOBE's Cultural Distance } \\
\hline $\begin{array}{l}\text { GLOBE cultural } \\
\text { distance }\end{array}$ & $\begin{array}{l}-0.32 * \\
(-1.90)\end{array}$ & $\begin{array}{c}-0.63 * * * \\
(-3.70)\end{array}$ & $\begin{array}{c}0.71 \\
(1.37)\end{array}$ & $\begin{array}{c}-0.52^{* *} \\
(-2.04)\end{array}$ & $\begin{array}{c}-1.00 * * * \\
(-3.94)\end{array}$ & $\begin{array}{c}1.15 \\
(1.49)\end{array}$ & $\begin{array}{c}-0.15^{* *} \\
(-2.33)\end{array}$ & $\begin{array}{c}-0.30 * * * \\
(-3.94)\end{array}$ & $\begin{array}{c}0.07 \\
(0.70)\end{array}$ \\
\hline Observations & 1,091 & 567 & 524 & 1,091 & 567 & 524 & 1,091 & 567 & 524 \\
\hline Left censored obs. & 868 & 399 & 469 & 868 & 399 & 469 & & & \\
\hline Log likelihood & -770.1 & -511.6 & -199.3 & -871.4 & -586.6 & -223.4 & -269.0 & -165.4 & -85.0 \\
\hline \multicolumn{10}{|c|}{ Panel III. WVS's Cultural Distance } \\
\hline $\begin{array}{l}\text { WVS cultural } \\
\text { distance }\end{array}$ & $\begin{array}{c}-0.54 * * \\
(-1.99)\end{array}$ & $\begin{array}{c}-0.53 * * \\
(-2.21)\end{array}$ & $\begin{array}{c}-0.90 \\
(-1.01)\end{array}$ & $\begin{array}{r}-0.85^{* *} \\
(-2.08)\end{array}$ & $\begin{array}{c}-0.94 * * \\
(-2.37)\end{array}$ & $\begin{array}{c}-0.97 \\
(-0.78)\end{array}$ & $\begin{array}{c}-0.26^{* *} \\
(-2.29)\end{array}$ & $\begin{array}{c}-0.31^{* *} \\
(-2.14)\end{array}$ & $\begin{array}{c}-0.21 \\
(-1.12)\end{array}$ \\
\hline Observations & 532 & 252 & 280 & 532 & 252 & 280 & 532 & 252 & 280 \\
\hline Left censored obs. & 432 & 174 & 258 & 432 & 174 & 258 & & & \\
\hline Log likelihood & -334.4 & -221.0 & -79.3 & -381.8 & -264.3 & -88.5 & -109.5 & -70.1 & -30.5 \\
\hline
\end{tabular}

Robust t-statistics in parentheses; $* * * \mathrm{p}<0.01,{ }^{* *} \mathrm{p}<0.05,{ }^{*} \mathrm{p}<0.1$

The table report regression estimation results using the sample of cross-listings from 45 home markets in 32 host markets as of December 2006 . Panel A reports results for the dependant variable the $\log G_{i j}$ defined as the number of cross-listings from home country $\mathrm{i}$ in host country $\mathrm{j}$, divided by the total number of domestic companies in the home country $\mathrm{i}: G_{i j}=C L_{i j} / D C_{i}$. Panel B reports results for the dependant variable the log $H_{i j}$ defined as the number of cross-listings listings from home country $\mathrm{i}$ in host country $\mathrm{j}$, divided by the total number of cross-listed companies from the home country $\mathrm{i}: H_{i j}=C L_{i j} / C L_{i}$. Both Panel A and B report Tobit model estimation results. Panel $\mathrm{C}$ reports results for the dependant variable $D C L_{i j}$, a dummy variable set to one if there are any cross-listings from home country $\mathrm{i}$ in host country j. Panel $\mathrm{C}$ reports Probit model estimation results. For each dependent variable the results are reported for the full sample, for developed and emerging home markets. GLOBE cultural distance is the cultural distance between the home country $i$ and host country $j$ calculated as the Euclidean Distance using culture scores from the GLOBE project (House et al, 2004). WVS cultural distance is the cultural distance between the home country $i$ and host country $j$ calculated as the Euclidean Distance using culture scores from the World Value Survey (http://www.worldvaluessurvey.org/) calculated as national averages to the responses of three questions focusing on Trust, Hierarchy and Egalitarianism. All regressions include the same set of control variables as in Table 3; the estimates of control variables are not reported. 